\title{
Strengths-based teaching and learning approaches for children: Perceptions and practices
}

\author{
Rod Galloway ${ }^{1}$, Bronwyn Reynolds ${ }^{2}$ and John Williamson ${ }^{3}$ \\ ${ }^{1}$ George Street Normal School, Dunedin, New Zealand (ORCID: 0000-0001-5075-8125) \\ ${ }^{2}$ School of Education, University of Tasmania, Australia (ORCID: 0000-0003-4821-385X) \\ ${ }^{3}$ School of Education, University of Tasmania, Australia (ORCID: 0000-0002-8809-8625)
}

\begin{abstract}
The development of children's strengths is essential for their success at school. Processes that assist children to recognise and act on their strengths, collectively referred to as "strengths-based approaches" in this study, are one aspect in the relatively new field of positive education that have been adopted enthusiastically by teachers for their reported constructive purpose and focus on improving student achievement and wellbeing outcomes. In recent years, however, the use of strengths-based approaches in New Zealand schools has moved beyond that warranted by the limited research base. In this study, qualitative data were collected to report on the perceptions and practices of common strengths-based teaching and learning approaches, as described by children, parents and teachers in a New Zealand primary school. Three separate sets of data were collected using a case study approach. The first data set involved 16 ten-year-old children; the second data set involved 15 parents of the child participants; and finally, five teachers of the children involved in the research were participants in the third data set. In light of the paucity of New Zealand studies in strengths-based teaching and learning approaches for children, this study aims to contribute to the knowledge in these areas and identify topics that warrant further investigation.
\end{abstract}

Keywords: Children; Strengths; Strengths-based; Self-efficacy; Engagement; Wellbeing

Article History: Submitted 17 July 2019; Revised 13 December 2019; Published online 25 January 2020

\section{Introduction}

Interest in how strengths-based approaches and positive education may be influencing student learning and wellbeing is increasing (Huebner, Gilman, Reschly \& Hall, 2009). Reasons cited for the emergence and popularity of positive psychology and more recently, positive education, include the development and availability of positive phenomena measures; a global awareness of optimal human functioning in the absence of war and economic depression; and a growing interest from the media and clinical practitioners (Diener, 2009). Furthermore, Seligman (2012) posits that positive education signals a new educational approach by closely linking student wellbeing with academic achievement. Norrish and Vella-Brodrick (2009) point out, however, that aspects of positive psychology have been of interest to behavioural scientists and philosophers for many years. Research into the environmental factors that allow happiness and high achievement to exist

Address of Corresponding Author

Rod Galloway, EdD., 10 Thornly Park Ave, Dunedin 9024 New Zealand.

$\bowtie$ rod@rodgalloway.com

How to cite: Galloway, R., Reynolds, B., \& Williamson, J. (2020). Strengths-based teaching and learning approaches for children: Perceptions and practices. Journal of Pedagogical Research, 4(1), 31-45. 
and thrive is well established, and now reframed as a positive psychology movement described as having a "very long past but only a very short history" (Peterson, 2006, p. 4). One direction to emerge from this new thinking is the application of positive psychology principles to education, and the implementation of "strengths-based approaches" (Noble \& McGrath, 2015).

Although the notion of utilising student's strengths to influence student learning potential has been the topic of a number of studies (Brownlee, Rawana \& MacArthur, 2012), there seems to be few documented examples of the practices and processes used for strengths identification, application and development, particularly through the lenses of children, their parents and teachers. With this in mind, two issues warrant further investigation within a New Zealand context: first, the literature reveals uncertainty regarding the precise nature of strengths-based approaches in schools (e.g., Biswas-Diener, Kashdan \& Minhas, 2011). Without knowing what strengths-based approaches are available for children, teachers are less able to make informed choices about learning programmes. Secondly, there is a paucity of research demonstrating the benefits and challenges of using strengths-based approaches with children (Biswas-Diener, et al., 2011), despite claims of improved student achievement and wellbeing (Seligman, Ernst, Gillham, Reivich, \& Linkins, 2009). School leaders may be tempted to embrace strengths perspectives due to the suggestion that identifying and nurturing strengths in children may have profound long-term gains (Linley, 2008), without knowing the relevant research base.

\subsection{Theoretical framework}

\subsubsection{Strengths-based approaches for children}

In this study, the term, "strengths" refers to children's abilities in various activities, ways of thinking and character traits, that they believe to be authentic, energising and performed well (Linley, 2008). Participants in the study, for example, named strengths such as: reading, cricket, problem-solving and kindness. Educational processes that incorporate children's strengths are referred to in the literature as, "strengths-based approaches", a term borrowed from the fields of social work and clinical psychology where the focus is on using a person's strengths and assets to assist problem resolution (Pattoni, 2012). Strengths-based approaches are strategies that identify, apply and develop children's strengths to enhance student learning and wellbeing (Quinlan, Swain \& Vella-Brodrick, 2012; Department of Education and Early Childhood Development, 2012). In addition, Noble and McGrath (2015) argue that the emphasis placed on character strengths in the literature needs to be broadened to include other strength domains.

\subsubsection{Theoretical context}

Deci and Ryan's (2000) self-determination theory (SDT) offers a conceptual understanding of how strengths-based approaches may influence student learning. According to Deci and Ryan, optimal human functioning is achieved when the psychological needs of autonomy, competence and relatedness are met. Viewed through the lens of SDT, strengths-based approaches may, for example, enable children to: feel competent by identifying what they do well and what they learn quickly (Seligman, 2012); experience autonomy by providing opportunities to name and act on their own strengths (Brownlee, Rawana \& McArthur, 2012) making learning choices and setting strengths-based goals (Lopez \& Louis, 2009); and gain a sense of relatedness by working with others on various strengths-related tasks (Lopez \& Louis, 2009). The suggested outcomes of SDT include improved intrinsic motivation and well-being (Deci \& Ryan, 2000) for children as young as eight years of age (Veronneau, Koestner \& Abela, 2005).

Seligman's (2012) well-being theory is also nominated to situate the current study and provide an overarching contextual perspective. Well-being theory is a multidimensional construct that advances the notion of strengths application to propose five contexts and indicators of well-being: (1) positive emotions, (2) engagement, (3) relationships, (4) meaning, and (5) accomplishment, collectively referred to as "PERMA" (Seligman, 2012, p. 16). Well-being theory suggests that the use of strengths leads to "more positive emotion, to more meaning, to more accomplishment, and 
to better relationships" (Seliman, 2012, p. 24) and was used to provide a contextual basis for the interpretation of findings in the study.

With these theories, descriptions and definitions in mind, the literature suggests that strengthsbased approaches can be related to high wellbeing outcomes (White \& Waters, 2015), such as hope and positive coping (Madden, Green \& Grant, 2011; Waters, 2015), increased enjoyment at school (Seligman et al., 2009), and assisting teachers to recognise what motivates and inspires children (Madden, Green \& Grant, 2011). Strengths-based approaches have also been associated with increased student engagement (Madden, Green \& Grant, 2011; Seligman et al., 2009; Quinlan, Swain, Cameron, \& Vella-Brodrick, 2015) and improved academic achievement (Seligman et al., 2009). Despite these findings, there remains few studies regarding strengths-based approaches that include children and their parents as participants.

In this context, the aim of this qualitative study was to investigate the perceptions and practices of strengths-based approaches for children in a New Zealand primary school with two research questions in mind: (1) How do children, teachers and parents in the study perceive the influence of identifying, applying and developing children's emerging strengths, on their learning and wellbeing, and (2) what are key stakeholders' perceptions about the effectiveness and challenges of implementing strengths-based approaches for children?

\section{Method}

\subsection{Research design and participants}

A small opportunity sample comprised of sixteen children (eight boys and eight girls), aged 10 years old (the children's data set), their parents (the parents' data set) and their teachers (the teachers' data set) participated in the project, from a larger opportunity sample of 90 possible children of this age, attending a large urban, decile 9 (regarded as a high socioeconomic rating) primary school in New Zealand. The participants had been involved in an existing school-wide strengths-based intervention for at least one year.

Although one of the three researchers was the principal of the school involved in the study, a variety of measures were taken to gain ethics approval from the University of Tasmania Ethics Committee and to ensure the research was not unduly influenced by a researcher's individual perspective. The researcher's role in the research, for example, was disclosed to all participants in a transparent and truthful manner, stating that the researcher would have no knowledge of any participant's identity and that the researcher's roles would be disclosed in any report of the research. Furthermore, a research assistant, not associated with the school, was employed and trained to manage various stages of the project to protect the identity of the participants. The involvement of the research assistant ensured that the researchers did not contribute to the recruitment of participants, or the consent and data collection processes. In addition, the research assistant conducted all interviews using audio-recording to allow accurate transcription. No participants were identifiable in the recordings and the researchers only had access to de-identified interview transcripts. The research assistant also collected, de-identified and coded all child and teacher documents used in the study. No participants were identifiable to the authors of this paper.

\subsection{Data collection tool}

\subsubsection{Semi-structed questionnaires}

Self-completed, semi-structured questionnaires were chosen to elicit responses from child, parent and teacher participants concerning their opinions, experiences and knowledge (Tuckman \& Harper, 2012) of strength-based approaches, as well as justification for their views (Stewart \& Shamdasani, 2014). The three semi-structured questionnaires included a mixture of open-ended and closed-ended peer reviewed questions designed to collect a variety of data (Sharp, 2012) and fulfil the aims of this study. Participants were often asked to respond to an open-ended question, 
explaining or justifying an answer to a previous closed-ended question. Child participants were asked, for example, if their strengths helped them to take part in class activities. Regardless of the "yes" or "no" responses to this closed-ended question, an open-ended question: "Why do you think this?" followed. The inclusion of questionnaires as one of three data gathering tools was considered appropriate to provide potential validation of findings from other collection methods and to assist with the qualitative nature of the study. The collection of vignettes and biographical details in the questionnaires, for example, provided rich narrative data that informed the design of semi-structured interview questions that followed. Consideration was given to Sharp's (2012) suggestion that questionnaires for children should be "shorter, simpler and perhaps more attractively set out and appealing than those for adults" (p. 69) and that "piloting in advance is essential" (p. 69).

In total, questionnaires were returned by five teachers responding to 10 open-ended questions and seven closed-ended questions; 14 parents responding to 12 open-ended questions and four closed-ended questions (as well as one parent who only returned the first page of the questionnaire); and 16 children responding to 21 open-ended questions and four closed-ended questions.

\subsubsection{Semi-structed focus group interviews}

Three semi-structured focus group interviews were conducted involving 5 of the 16 children, 4 of the 16 parents and 4 of the 5 teachers. Focus group interviews were deemed an appropriate tool for data collection due to the ability of the interviewer to check participant's understanding of the question (Mutch, 2013), probe for further responses (Creswell, 2013) and explanations of perceptions (Yin, 2013). The purpose of the focus group interviews was to explore the participant's knowledge, perceptions and experiences concerning any relationship between the use of strengthsbased approaches and children's learning, using a series of semi-structured questions (see Table 1, below). Topics of interest included participants' perceptions on the effectiveness and challenges of strengths-based approaches and strategies.

A number of ethical considerations concerning interviewing children were made in the current study including allowing children to determine the pace of the interview (Sharp, 2012); ensuring the absence of the children's teachers (Cohen, Manion \& Morrison, 2000); reassuring children that they could decide not to answer questions (Sharp, 2012); and inviting children to ask any questions (Tuckman \& Harper, 2012).

Table 1.

Types of Interview Questions used in Focus Group Interviews

\begin{tabular}{|c|c|c|c|c|}
\hline $\begin{array}{l}\text { Interview } \\
\text { question type } \\
\text { (Kvale, 1996) }\end{array}$ & Question example & $\begin{array}{l}\text { Number of } \\
\text { questions } \\
\text { for children }\end{array}$ & $\begin{array}{c}\text { Number of } \\
\text { questions for } \\
\text { teachers }\end{array}$ & $\begin{array}{l}\text { Number of } \\
\text { questions for } \\
\text { parents }\end{array}$ \\
\hline $\begin{array}{l}\text { Introduction } \\
\text { (Warm up) }\end{array}$ & Does everyone have strengths? & 2 & 0 & 1 \\
\hline $\begin{array}{l}\text { Probing } \\
\text { (Explain further) }\end{array}$ & What makes you think that? & 9 & 5 & 8 \\
\hline $\begin{array}{l}\text { Follow up } \\
\text { (Provide an example) }\end{array}$ & Can you provide an example? & 8 & 2 & 4 \\
\hline $\begin{array}{l}\text { Specifying } \\
\text { (List or Describe) }\end{array}$ & $\begin{array}{l}\text { What are some of the strengths-based } \\
\text { approaches you use in the classroom to allow } \\
\text { children to develop (grow) new and existing } \\
\text { strengths? }\end{array}$ & 2 & 3 & 5 \\
\hline $\begin{array}{l}\text { Direct } \\
(\text { Yes/No) }\end{array}$ & $\begin{array}{l}\text { Should finding and improving your strengths } \\
\text { be taught at every school? }\end{array}$ & 2 & 7 & 12 \\
\hline $\begin{array}{l}\text { Interpreting } \\
\text { (Opinion) }\end{array}$ & $\begin{array}{l}\text { What is the most important to learning - } \\
\text { discovering new strengths, or using your } \\
\text { strengths, or improving the strengths you have? }\end{array}$ & 5 & 3 & 1 \\
\hline
\end{tabular}




\subsubsection{Document analysis}

In the current study, information about events, experiences and processes produced by teachers and children, was collected and de-identified before being analysed using a framework of questions informed by the aims of the study. Documents collected were mainly in the form of descriptive text that MacDonald and Tipton (1996) classify as private papers. Only documents from a primary source, that is, documents produced by a child or teacher involved in the study, were collected. Although 98 examples of 25 primary source documents were collected, only 55 examples of 17 document types were deemed appropriate and useful to the aims of the study. Twelve examples of 9 document types produced by teachers were used (see Table 2, below) and 43 examples of eight document types produced by children were used (see Table 3, below).

Table 2.

Summary of Documents Produced by Teachers

\begin{tabular}{|c|c|c|c|}
\hline Document title & $\begin{array}{l}\text { Number of } \\
\text { examples } \\
\text { collected }\end{array}$ & $\begin{array}{c}\text { Number of } \\
\text { examples } \\
\text { used }\end{array}$ & Application to current study \\
\hline $\begin{array}{l}\text { Reflecting about } \\
\text { Electives }\end{array}$ & 1 & 1 & $\begin{array}{l}\text { Teacher's planning to assist children with } \\
\text { evaluation of their strengths }\end{array}$ \\
\hline $\begin{array}{l}\text { Lesson Plan - strengths } \\
\text { and weaknesses }\end{array}$ & 1 & 1 & $\begin{array}{l}\text { Teacher's planning to apply children's } \\
\text { strengths }\end{array}$ \\
\hline $\begin{array}{l}\text { Teaching as inquiry } \\
\text { planning }\end{array}$ & 1 & 1 & $\begin{array}{l}\text { Teacher's planning to apply children's } \\
\text { strengths }\end{array}$ \\
\hline Science and the sea & 1 & 1 & $\begin{array}{l}\text { Evaluation of children's strength } \\
\text { development }\end{array}$ \\
\hline $\begin{array}{l}\text { Our classroom } \\
\text { (code of conduct) }\end{array}$ & 1 & 1 & $\begin{array}{l}\text { Teacher's planning to guide the strength } \\
\text { classroom culture }\end{array}$ \\
\hline $\begin{array}{l}\text { Student report } \\
\text { comments }\end{array}$ & 4 & 1 & $\begin{array}{l}\text { Evaluation of children's strength } \\
\text { development }\end{array}$ \\
\hline $\begin{array}{l}\text { Electives promotional } \\
\text { statements }\end{array}$ & 6 & 1 & Strengths-related planning \\
\hline Student profiles & 3 & 3 & $\begin{array}{l}\text { Evaluation of children's strength } \\
\text { development }\end{array}$ \\
\hline $\begin{array}{l}\text { Strengths related child } \\
\text { references }\end{array}$ & 2 & 2 & $\begin{array}{l}\text { Evaluation of children's strength } \\
\text { development }\end{array}$ \\
\hline Other documents & 1 & 0 & Not applicable \\
\hline Total & 21 & 12 & \\
\hline
\end{tabular}

Table 3.

Summary of Documents Produced by Children

\begin{tabular}{lccl}
\hline Document title & $\begin{array}{c}\text { Number of } \\
\text { examples } \\
\text { collected }\end{array}$ & $\begin{array}{c}\text { Number of } \\
\text { examples } \\
\text { used }\end{array}$ & Application to current study \\
\hline Learning Commitment & 15 & 15 & $\begin{array}{l}\text { Strengths inventory and goal-setting } \\
\text { Strengths mind map }\end{array}$ \\
"3eMe" join the dots & 6 & 6 & $\begin{array}{l}\text { Strengths inventory } \\
\text { Strengths inventory }\end{array}$ \\
activity & 7 & 7 & Strengths inventory \\
What are some of my & 6 & 1 & Strengths-based goal-setting \\
strengths? & 4 & 4 & Strengths-based goal-setting \\
Strengths action plan & 7 & 3 & Strengths-based goal-setting \\
Reflective statement & 6 & 6 & Strengths application \\
Maths spider web & 3 & 1 & Not applicable \\
Scholarship application & 23 & 0 & \\
Other documents & 77 & 43 & \\
\hline Total & & & \\
\hline
\end{tabular}




\subsection{Data analysis}

The three data sets (children, parents and teachers) were analysed and interpreted using an inductive approach to locate emergent themes and sub-themes. Keyword analysis (Savin-Baden \& Major, 2013) was employed by researchers to look for "frequently repeated words, unusual words and words used in context with other words" (p. 43) as well as "constant comparison", noting and comparing significant ideas with other findings in the data and other studies and theories (Babbie, 2014). The data were made available to participants for checking prior to analysis.

\subsubsection{Data validity}

After completing a thematic analysis within each of the three data sets, comparisons between each of the cases and finally, across the entire collection were employed to ensure individual and holistic perspectives were included and potential triangulation of the data considered (Denzin, 1989).

\section{Results}

\subsection{Children's data set}

The majority of children in the study knew about their strengths and related involvement at school. In the questionnaire, for example, children were asked about any relationship between their strengths and their learning. In total, 13 out of the 15 children indicated that a nominated strength helped them to learn at school ( 2 of the 13 children chose not to answer this question). When asked about their strengths and participation in learning tasks at school, most children (15 participants out of a possible 16), completing the self-administered questionnaire, responded with examples that included, mathematics (two children); reading (four children); making friends, drama and art (three children); and writing and spelling (two children). When asked about the feelings generated by long engagement in an area of strength, questionnaire responses included: "proud" (five children); "really good" (three children); and "pleased" (two children). One child described the length of engagement as:

"losing track of time and feeling happy and satisfied. Also, rather hungry". (Questionnaire Child Twelve (C12))

Nine children from the 16 who completed the questionnaire considered "enjoyment" to be a prerequisite of any nominated strength (combined with "being good" at something). Three of these children specifically mentioned that involvement in strengths-related activities was enjoyable and three others expressed feelings of excitement when actively involved in strengths-related tasks.

During the focus group interview, children were asked if any programmes, offered at school, assisted them to identify, apply or develop their strengths. Three different strengths-based programmes were nominated: (1) "strengths-based learning time", described by Child 5 as a timetabled class session for children to develop their strengths on an individual basis, (2) the choice of strengths-aligned elective classes, and (3) opportunities, within the normal classroom programme, to pursue a strengths-related aspect of the curriculum.

Documents provided by the children revealed perceptions of success relating to a learning goal associated with their strengths (referred to as a "strengths-based learning goal"). On their strengths-based learning goal document, thirteen of the 16 children involved in the study had shaded either an "unhappy face" (*) indicating poor progress, a "straight mouth face" $(\oplus)$ indicating satisfactory progress, or a "happy face" (-) indicating goal achievement. In at least one of the two opportunities provided annually by teachers to review their strengths-based goal, five of the 13 children considered their progress as satisfactory and eight of the 13 children rated their progress as good. One child, for example, commented: 
"I think I've done well ... in my strength goal - to plan, write and perform a play. [Child A] and [Child B] are acting in it, I've written it and practiced and we'll be performing it very soon! I think it's really helped with my creativity, writing and drama". (Document Child 12 (DC12)).

Another child wrote in a reflection activity about the feelings associated with his or her strengths:

"I am proud of my strengths and not only have I had fun but I have improved ... I love my strengths and I hope I never lose them". (DC3)

Children participating in the focus group interview raised the topic of time constraints on strengths-related activities as a potential barrier to the effectiveness of strengths-based approaches. All children indicated their preference for more time to be spent on strengths-related activities, with suggestions ranging from daily for ten minutes to longer sessions, twice per week. Reasons provided to justify increased opportunities included, fully utilising school resources, participating in new experiences and the potential for improved concentration in class following involvement in a strengths-related activity.

\subsection{Parent's data set}

Overall, the parents' data revealed support for the notion that the acknowledgement and mobilisation of children's strengths assists their learning. In the questionnaire, for example, parents were asked about their child's strengths and opportunities to use them at school. References to goal success and positive teacher/pupil relationships were reported as aspects of effective strengths-based approaches. Parents' comments included:

"In terms of those strengths-based approaches, positive relationships teachers form with children, with the knowledge of their strengths. My son's teacher ... relates various different strengths together ... just naturally extends some of his interests and strengths... as you see links between strengths and because they get on very well he can do it in very casual, conversational sort of way'. (Interview Parent Six (IP6))

"He is able to apply himself to a task without distraction, so learns more quickly and completely". (Questionnaire Parent Seven ( QP7))

"There has been a focus on strengths and there has been a rise in achievement". (IP10)

One parent wrote that their child's strengths help them learn because of the increase in confidence and enjoyment (QP4). That was supported by a further parent who mentioned strengths activities inspired and motivated their child in a "positive experience" (QP9). In one of the questionnaire responses, a parent provided a list of out-of-class strengths-related activities that resulted in a perceived increase in confidence and wellbeing. This boost in confidence, according to the parent, enabled their child to be better equipped to negotiate difficulty at school:

"Stronger confidence at home equals more resilience at school". (QP10)

Another finding evident in the parents' data was the perception that a school-wide strengthsbased intervention was important when recognising and valuing children's strengths, whatever those strengths might be. During the focus group interview, for example, parents discussed the perceived merit of enabling all children in know and use their strengths:

Parent 4: "I feel in this school that... their strengths will be valued and it mightn't be...the most wonderful strength in the world that's going to be world changing but for that person or that child it is valued and... is sort of honored in a way".

Parent 10: "And it certainly is a flavor, I'd agree, around here that you know each child has a contribution, a unique contribution and people, the rest of the school is missing out if their unique set of skills and ah who they are wasn't present you know. ... just get that sense in that regard they may not be the South Island champ at chess or the captain of the rugby team but maybe you know something totally out of left field and if that's missing then the school is poorer for it and I think that sort of culture is great".

Parent 4: "And it might be you know for example that a child has the sweetest nature or the kindest person or something like that, they're things that you know..." 
Parent 14: "...it's holistic..."

Parent 4: "...yeah it's holistic and I just would always want to be sure that if was a strengths-based approach was applied, it was applied in that way and that you know is honored as much as the other outstanding sort of things".

Parent 4: "...not everyone's an outstanding achiever...I mean my son's quite weird so I find it quite difficult..."

Parent 14: "...they're all weird..."

Parent 10: "...that could be a strength...(everyone laughs)"

Parent 4: "Well it is a strength actually because...he's his own person and he would never agree with you for the sake of agreeing you know and he achieves at a high level when he's interested in something".

Another clear finding from the parents' data was that 12 of the 14 participants believed their child's strengths influenced their level of engagement at school. Comments from these parents included:

"She was good at one thing and she had, she eventually had belief in herself that she could do something else, you know, grow something ... I guess it was building on one strength to try and build the leadership things and confidence in herself". (IP4)

"This child is not strong academically despite a lot of hard work at school and at home over many years. However, he still has great personal confidence and a willingness to engage and pick up new opportunities because he knows he has other strengths - and that's ok". (QP3)

\subsection{Teachers' data set}

Teachers were able to describe a range of strengths-based approaches and related activities they considered to be effective. The strengths-based approach of creating an awareness of children's strengths using an identification process included the "3eMe join the dots" task that was used by teachers to promote the understanding and recognition of a strength as more than something children are just good at. In this activity, nominated by all five teachers as effective, children were encouraged to create three lists of anything they considered themselves: (1) to excel in, as an indicator of a strength (Linley, 2008), (2) to be excited by, as an indicator of a strength (Govindji \& Linley, 2007), or (3) to enjoy, as an indicator of a strength (Seligman, 2012). Each item could be repeated in the excel, excite or enjoy list, if that was true for the child. Children were then asked to look for the common items in the three "excel, excite, and enjoy" lists and draw connecting lines between them, demonstrating an association between these ideas and signaling possible areas of strength. Comments relating to the " $3 \mathrm{eMe}$ join the dots" activity included:

\footnotetext{
"3e's very effective (real range of ideas and kid speak". (Questionnaire Teacher Five (QT5))

"Using structures such as 3eMe help strategies such as classifying of strengths". (QT3)

"The 3eMe triangle is very useful to help determine which strength to select as a focus area". (QT1)

"Children like to see they have connections between all three". (QT2)

"...they looked at the three E's and what they enjoy and what excites them, and what they excel at, when they looked at all three, some appeared in all three so when it came to the parent interview it was quite easy to set a goal that was attainable and measurable with a parent who could also identify with those strengths that the child had identified". (Interview Teacher Two (IT2))
}

Another strengths identification activity, nominated by all five teachers, was a sample list of strengths ("What are some of my strengths?") that provided children and parents with ideas of strengths under the headings of action strengths, character strengths and thinking strengths (Linley \& Harrington, 2006). In this activity, children were encouraged to discuss strength-spotting (Linley, 2008) ideas and then mark (using a highlighter pen) any strengths listed that may apply to them, as well as stating any that did not appear in the lists. In the questionnaire, teacher comments relating to the "What are some of my strengths survey" included:

"What are some of my strengths survey is an effective way to help parents and children become strength detectives, as it gives some suggestions for each strength area". (QT4) 
"Having samples of strengths in different areas helps children to identify their own strengths". (QT3)

"It was helpful to read each out and provide explanations where necessary. Children also liked to add their own. This was an effective list for parents as well and helpful during the interview process". (QT2)

"Extremely helpful as a guideline as parents and children immediately notice strengths listed that they may not otherwise have considered". (QT1)

In addition to strengths identification activities, teachers acknowledged effective strengths application and development activities were often repeated in both categories. Strengths-based goal-setting, for example, was mentioned by three teachers as a strengths application activity, and by two teachers as a strengths development activity. Six of the 11 learning goal documents, provided by teachers, showed shading over a "straight line face", indicating satisfactory progress, while 5 of the 11 learning goal documents provided by teachers included shading over a "smiley face" communicating that the strengths-based goal had been achieved. Other strength application and development activities nominated by teachers included: using self-visualisation techniques for strengths-based outcomes; developing strengths in new and different ways; celebrating and sharing their strengths success; using curriculum contexts for strength development; and children teaching other children using their strengths.

Documents and statements provided by teachers indicate that following the identification of student strengths, a programme of student chosen elective classes were offered. Comments concerning strengths-based elective programmes included the opportunity for children to experience new and different areas of potential strengths (IT4) and strength development involving other children:

"Elective programmes offer children opportunities to develop their strengths while working alongside their peers". (QT1)

"Teachers and children using their strengths in a teaching role". (QT3)

All teachers mentioned the collaborative process of completing a "learning commitment" form, comprising: (1) a list of each child's strengths (using the categories of "action strengths", "character strengths" and "thinking strengths"), and (2) setting a learning goal based on one of their strengths.

"The learning commitment forms and interviews are great ways to get parents, children and teachers working collaboratively". (QT4)

"with the children setting and monitoring their goals, what I have found to be really effective is that we sign with parents and so to me it's a triangle and it's not just the child or the child and me". (IT1)

As well as descriptions of various strengths-based approaches and activities, teachers also commented on their perceptions of associated successful outcomes. Four of the five teachers completing the questionnaire, for example, stated the belief that children's strengths influenced engagement. One teacher was more cautious:

"With so many strengths and so many children it's hard to know". (QT5)

Teachers also referred to emotions associated with the enjoyment and engagement that could be linked to an area of strength:

"I just think about myself, and the things that I see as my strength and I really enjoy doing and I think it's the same with children". (IT1) SEEE?

"Engagement definitely [happens] with something that you enjoy". (IT3)

"The children enjoy strengths-based learning time and look forward to it weekly. They have set their goals and are responsible for the learning task and they really enjoy that. When they are working on something they enjoy and are good at, they show perseverance and resilience". (QT1)

"The children love having an opportunity to work on their strengths in class. They are highly motivated. 
Providing them with the chance to share them with the class has been successful. Where possible, these strength presentations have also been shared on the class blog". (QT4)

"You just can't stop him from talking, he just gets so excited and enjoys what he's produced and the process he goes through". (IT1)

"Very obvious changes in attitude and behaviour for some children". (QT3)

"Those who believe they have a strength in a particular learning area are more willing to take risks with their learning". (QT4)

"There are some children who find it difficult to engage in learning and then it comes to strengths-based learning time and it's really exciting to see their enthusiasm". (IT1)

"With under achieving students, it is good to have that common knowledge of their strengths, to be positive/have positive conversations with them". (QT5)

Responses from all five teachers highlighted several challenges associated with strengths-based approaches: (1) the need for teachers to encourage and enable children to recognise their own cognitive (thinking) and relationship (character) strengths. Some children were unable to reflect deeply enough on their strengths and tempted to focus just on activity-related strengths (QT3; IT3), (2) timetabling constraints make it difficult to provide strengths-related teaching and learning opportunities (IT3; QT2), (3) some children's lack of interest or investment in choosing and achieving a personally relevant strengths-based goal (IT3; IT2), and (4) lack of parental involvement in appropriate strengths-related goal selection, progress and achievement for their child (QT2; IT4).

\section{Discussion}

A strong finding to emerge from the three data sets (children, teachers and parents) was the perception that children's strengths may assist their learning. Although this finding is well supported in the literature (e.g., Shoshani \& Slone, 2013; Proyer, Ruch \& Buchor, 2013; Quinlan et al., 2012; Stebleton, Soria \& Albecker, 2012), there are few reports of the actual strengths-related processes, strategies and activities that promote the awareness and development of strengths specifically for children (Quinlan et al., 2015). In response to this gap in the literature, and highlighted in the findings of this study, practices for identifying, applying, and developing children's strengths are discussed next.

\subsection{Practices for identifying, applying, and developing children's strengths}

A uniform finding in the study was that all five teachers implemented: (1) processes for identifying children's strengths that involved the recognition and acknowledgment of children's preferences, abilities and passions (Linley \& Harrington, 2006), (2) processes for applying children's strengths when teachers encourage children to "be aware of what they can use those strengths to achieve, accomplish, and overcome" (Brownlee, Rawana \& MacArthur, 2012, p. 8), and (3) processes for developing children's strengths enabling students to improve known competencies (Biswas-Diener et al., 2011). These three processes were used in an intentional manner, for the explicit purpose of harnessing children's strengths for learning, by employing a total of 16 related strategies and activities. Although there were more strategies and activities associated with the identification of children's strengths than any other approach, the interrelated and interdependent process of identifying, applying and developing strengths was evident. Rawana, Latimer, Whitley and Probizanski (2009) contend that teachers can only create an awareness of strengths by using a specific identification process and teaching and learning programmes should assist children to learn about and apply their strengths. Biswas-Diener et al., (2011) point out, however, that without developing strengths, there is limited value in the processes of identifying and applying strengths. Regarding the interrelated nature of these processes, the results of this study are also consistent with Madden, Green and Grant (2011), who suggest strengths identification, application, and development processes can be ordered sequentially so that only when strengths are recognised, 
can they be applied; and only when applied, can they be developed. The following strategies and activities related to the identification, application, and development of strengths for children, and not found in the literature, were described in the study.

\subsubsection{Reflective tasks assisting children with the identification of their strengths.}

Given the reported importance of identifying strengths (Rawana et al., 2009), the seeming lack of age appropriate tasks for teachers and children to use is of concern. Brownlee, Rawana and MacArthur (2012) recommend following a deliberate approach to strengths identification to enable a broader conceptualisation of what a strength may be, beyond "being good at something". In the current study, examples of reflective tasks, intended to assist children with the identification of their strengths, included:

- "3eMe join the dots" strengths identification activity. As described earlier, children were invited to consider their strengths as a combination of three qualities, described by words beginning with the letter " $\mathrm{e}$ " (excel, excite and enjoy) set out on a page in a triangular shape. Lists of selfidentified areas of ability and interest were compiled beside each of the excel, excite and enjoy headings and a corresponding "dot" that could be connected with lines, drawn with a pen, between possible combinations of what children considered they were good at (excel), chose to do often (enjoy) and felt energised by (excite). Connecting all three dots indicated a possible area of strength.

- "What are some of my strengths?" identification lists focussing on three strength domains. A sample list of strengths, set out under the headings of action, character and thinking strengths, was provided for children to discuss, reflect on and identify any strengths that applied to them. Space was also provided at the end of each column (action strengths, character strengths, and thinking strengths) for children, once they had viewed the examples of strengths, to add their own ideas. Some teachers commented it was useful for children to see lists of strengths, even if they did not apply to them.

4.1.2. Inventory of children's strengths compiled in consultation with their parents and teacher, and understood to be multi-dimensional, non-exhaustive and subject to change.

A criticism of strengths-based approaches is the claim that acknowledging and naming children's strengths can lead to de-emphasizing areas of difficulty and weakness (Biswas-Diener et al., 2011) and promote the development of a fixed, rather than "growth mindset" (Dweck, 2006). Alternatively, Jach, Sun, Loton, Chin and Waters (2017) contend that once children have gone beyond identifying and using their strengths, a developmental aspect of their strengths involvement may be evident as a different and broader set of strength-related skills and abilities. The sooner children's strengths are named and in frequent use, the sooner the benefits of a strengths-related growth mindset can occur. Perhaps for this reason, Seligman (2012) suggests that children's strengths should be named from a young age. The literature also points to children's strengths expanding and dynamic in nature (e.g., Quinlan et al., 2012; Rawana et al., 2009; Norrish, Williams, O'Connor \& Robinson, 2013) with potential increases in wellbeing (Park \& Peterson, 2009) as more strengths are identified. One of the documents from the current study states that because children's strengths grow in number and evolve in nature, an identification process is not an attempt to finalise a permanent set of strengths, but rather, what children, parents and teachers may agree on, at that point in time and open to future modification. Furthermore, Brownlee, Rawana and MacArthur (2012) contend that the process of assembling a strengths inventory for each child assists teachers in their knowledge of students. The strengths lists provided by all children in this study include broad categories of action strengths, character strengths, and thinking strengths, in contrast to limiting categories to only "character strengths" as found in other published studies (Waters, 2017). It is suggested that any risks of nominating children's strengths at an early age may be less significant than the risks associated with underachievement and low student wellbeing if strengths are not acknowledged. In the current study, for example, children 
and parents were asked about student wellbeing (Noble, McGrath, Roffey \& Rowling, 2008), responding positively to questions about how engagement in tasks, using strengths at school, made children feel. In their review of positive psychology and classroom interventions, Seligman et al., (2009) conclude that children's wellbeing can be influenced by strengths-based approaches and that "more well-being is synergistic with better learning" (p. 294). It is suggested that confirming which strengths-based approaches influence high student wellbeing is a worthy topic for future investigation.

\subsubsection{Learning goals, related to children's strengths, set and monitored by children, parents and teachers.}

All five teachers negotiated learning goals (strengths-based goals) with children and parents that: (1) were aligned to children's strengths, (2) focused on effort and mastery, rather than performance, and (3) were expressed in language understood by children. Once agreed, strengthsbased goal progress and achievement was monitored and reported by teachers, children and parents twice per year. One of the outcomes of setting and achieving goals, mentioned by participants, was a perceived improvement in children's confidence, and in this context, referred to as "self-efficacy", described by Bandura (1986) as "beliefs in one's capabilities to organize and execute the courses of action required to manage prospective situations" (p. 2). In the study, the terms "self-efficacy" and "confidence" were occasionally used interchangeably. While it is acknowledged that confidence and self-efficacy can be considered conceptually different (Bandura, 1997), some researchers (e.g., Butz \& Usher, 2015) have found the use of the term "confidence" to be more understandable than self-efficacy, particularly with children. The early establishment of self-efficacy beliefs has been linked to improved student learning (e.g., Bandura, 1977; Joet, Usher \& Bressoux, 2011; Maatta, Jarvela \& Perry, 2015) and wellbeing (Schunk \& Mullen, 2012). Hattie (2012) concludes that students with high self-efficacy regard failure as opportunities to learn from and use their confidence to improve in the future. Although other studies have indicated causal links between strengths programmes and improved self-efficacy (e.g., Ruch, Weber, Park \& Peterson, 2014; vin Dinther, Dochy \& Segers, 2011), strengths-related self-efficacy for children, rather than adolescents and adults; and strength domains, such as "thinking strengths", rather than just in character strengths, warrant investigation. It may be appropriate for further research to focus on the notion that children's self-efficacy beliefs can be enhanced when: (1) strengths-based goals are set, focusing on improvement and effort, (2) strengths-based goals are set with an appropriate level of difficulty that requires resilience and perseverance, (3) children are directly involved in setting and monitoring their own strengths-based goals, and (4) children are motivated by observing other children achieving success in a strengths-based goal.

4.1.4 Learning choices, specifically related to children's strengths, offered as subject electives or class time allocated for the completion of strengths-based goals.

Another frequently mentioned strategy in the questionnaire responses relating to the identification, application, and development of children's strengths, was the provision of student choice (Rapp, Saleebey \& Sullivan, 2006). Teachers described the implementation of strengthsrelated elective classes, referred to as "electives", and the opportunity for children to complete strengths-based goals and other strengths projects, referred to as "strengths-based learning time", as regular aspects of their classroom programme. Opportunities for choice in the classroom have been shown to influence motivation and performance outcomes, particularly when the choices offered are relevant to a student's interests (Patall, Cooper \& Wynn, 2010). Although not specifically mentioned in the literature, "strengths-based elective classes" and "strengths-based learning time" may be examples of how teachers can cater for children's strengths through the provision of student choice.

\section{Limitations and Future Implications}

Three limitations of this small-scale study are noted. First, the study was reliant on the use of children's, teachers' and parents' self-report data. Issues of accuracy and validity are raised when 
self-reported data, such as opinions and perceptions, are relied upon (Chan, 2009). Reflections and recollections may be imperfect and subject to what can be remembered, understatement or exaggeration (Kormos \& Gifford, 2014). Secondly, participants were drawn from one type of school classified as having a high socioeconomic rating. Lareau (2011) regards family income to be a significant factor in children having opportunities to participate in strength-related programmes, and therefore, potentially improved self-awareness. Lastly, one of the researcher's role as the principal of the school where the research took place is acknowledged as a limitation despite processes to ensure the research was not unduly influenced by this researcher's individual perspective.

While the argument that fixed mindsets can limit children's effort, progress and achievement (Dweck, 2006) needs to be considered, the benefits of early identification of children's strengths appear to be important for two reasons: (1) the stated importance of strengths development (Biswas-Diener et al., 2011) cannot occur without strengths first being identified. In the current study, for example, the naming of children's action strengths, character strengths and thinking strengths, enabled developmental strengths-based goals to be set and achieved, and (2) the identification of strengths can produce positive emotions, resulting in increased self-efficacy. Practices such as using strengths identification activities, strengths-related learning choices and strengths-based learning goals, with children from an early age, may add to the relevant research base regarding how strengths-based approaches contribute to enhanced student wellbeing and learning outcomes.

\section{References}

Babbie, E. (2014). The basics of social research (6th ed.). Belmont, CA: Wadsworth/Centage Learning.

Bandura, A. (1977). Self-efficacy: Toward a unifying theory of behavioral change. Psychological Review, 82, $191-215$.

Bandura, A. (1986). Social foundations of thought and action: A social cognitive theory. Englewood Cliffs, NJ: Prentice-Hall.

Bandura, A. (1997). Self-efficacy: The exercise of control. New York, NY: W H Freeman/Times Books/ Henry Holt \& Co.

Biswas-Diener, R., Kashdan, T. B., \& Minhas, G. (2011). A dynamic approach to psychological strength development and intervention. The Journal of Positive Psychology, 6(2), $106-118$. http:/ / dx.doi.org/10.1080/17439760.2010.545429

Brownlee, K., Rawana, E. P., \& MacArthur, J. (2012). Implementation of a strengths-based approach to teaching in an elementary School. Journal of Teaching and Learning, 8(1), 1-12. https://doi.org/10.22329/jtl.v8i1.3069

Butz, A.R., \& Usher, E.L. (2015). Salient sources of early adolescents' self- efficacy in two domains. Contemporary Educational Psychology. 42, 49-61. http:/ / dx.doi.org/10.1016/j.cedpsych.2015.04.001

Chan, D. (2009). So why ask me? Are self-report data really that bad? In C. E. Lance \& R. J.

Vandenberg (Eds.), Statistical and methodological myths and urban legends: Doctrine, verity and fable in the organizational and social sciences (pp. 309-335). New York, NY: Routledge.

Cohen, L., Manion, L., \& Morrison, K. (2000). Research in education. London, UK: Routledge Falmer.

Creswell, J. W. (2013). Research design: Qualitative, quantitative, and mixed methods approaches (4th ed.). Thousand Oaks, CA: Sage.

Deci, E. L., \& Ryan, R. M. (2000). The "what" and "why" of goal pursuits: Human needs and the selfdetermination of behavior. Psychological Inquiry, 11(4), 227-268.

Denzin, N. K. (1989). The research act: A theoretical introduction to sociological methods (3rd ed.). Englewood Cliffs, NJ: Prentice Hall.

Department of Education and Early Childhood Development. (2012). Strength-based approach. A guide to writing transition learning and development statements. Melbourne, Australia: State of Victoria.

Diener, E. (2009). Positive psychology: Past, present, and future. In S. J. Lopez \& C. R. Snyder (Eds.), Oxford handbook of positive psychology (2nd ed., pp. 7-11). New York, NY: Oxford University Press.

vin Dinther, M., Dochy, F., \& Segers, M. (2011). Factors affecting students' self-efficacy in higher education. Educational Research Review, 6(2), 95-108. http:/ /dx.doi.org/10.1016/j.edurev.2010.10.003 
Dweck, D. (2006). Mindset, the new psychology of success. New York, NY: Random House.

Govindji, R., \& Linley, P. A. (2007). Strengths Use, Self-Concordance and Well-Being: Implications for Strengths Coaching and Coaching Psychologists. International Coaching Psychology Review, 2, 143-153.

Green, L. S., Oades, L. G., \& Robinson, P. L. (2012). Positive education programmes: Integrating coaching and positive psychology in schools. In Christian van Nieuwerburgh (Ed.), Coaching in education: Getting better results for students, educators, and parents (pp. 115-132). London, UK: Karnac Books.

Hattie, J. (2012). Visible learning for teachers: Maximising impact on learning. New York, NY: Routledge.

Huebner, E. S., Gilman, R., Reschly, A., \& Hall, R. (2009). Positive schools. In S. J. Lopez \& C. R. Snyder (Eds.), The Oxford handbook of positive psychology (2nd ed., pp. 561-569). New York, NY: Oxford University Press. https:// doi.org/10.1093/oxfordhb/9780195187243.013.0053

Jach, H. K., Sun, J., Loton, D., Chin, T. C., \& Waters, L. E. (2017). Strengths and subjective wellbeing in adolescence: Strength-based parenting and the moderating effect of mindset. Journal of Happiness Studies, 1-20. https:// doi.org/10.1007/s10902-016-9841-y

Joët, G., Usher, E. L., \& Bressoux, P. (2011). Sources of self-efficacy: An investigation of elementary school students in France. Journal of Educational Psychology, 103(3),

649-663. http:/ / dx.doi.org/10.1037/a0024048

Kirschman, K. J. B., Johnson, R. J., Bender, J. A., \& Roberts, M. C. (2009). Positive psychology for children and adolescents: Development, prevention, and promotion. In S. J. Lopez \& C. R. Snyder (Eds.), The Oxford handbook of positive psychology (2nd ed., pp. 133-148). New York, NY: Oxford University Press.

Kormos, C., \& Gifford, R. (2014). The validity of self-report measures of pro-environmental behavior: A $\begin{array}{llll}\text { meta-analytic } & \text { review. Journal }\end{array}$ http:/ / dx.doi.org/10.1016/j.jenvp.2014.09.003

Kvale, S. (1996). Interviews: An introduction to qualitative research interviewing. Thousand Oaks, CA: Sage.

Lareau, A. (2011). Unequal childhoods: Class, race, and public life with an update a decade later. Los Angeles, CA: University of California Press.

Linley, A. (2008). Average to A+: Realising strengths in yourself and others. Coventry, United Kingdom: CAPP Press.

Linley, P. A., \& Harrington, S. (2006). Playing to your strengths. The Psychologist, 19(2), 86-89.

Lopez, S. J., \& Louis, M. C. (2009). The principles of strengths-based education. Journal of College and Character, 10(4), 1-8.

Määttä, E., Järvelä, S., \& Perry, N. (2015). Personal and contextual contributors to young children's activitybased perceived self-efficacy. Scandinavian Journal of Educational Research, 1-18. http:/ / dx.doi.org/10.1080/00313831.2015.1024161

MacDonald, K. \& Tipton, C. (1996). Using documents. In N. Gilbert (Ed), Researching social life (pp. 187-200). London, UK: Sage.

Madden, W., Green, S., \& Grant, A. M. (2011). A pilot study evaluating strengths-based coaching for primary school students: Enhancing engagement and hope. International Coaching Psychology Review, 6(1), 71-83.

Mutch, C. (2013). Doing educational research: A practitioner's guide to getting started (2nd ed.). Wellington, New Zealand: New Zealand Council for Educational Research Press.

Noble, T., \& McGrath, H. (2015). PROSPER: A new framework for positive education. Psychology of WellBeing, 5(1), 2. http:/ / dx.doi.org/10.1186/s13612-015-0030-2

Noble, T., McGrath, H., Roffey, S. \& Rowling, L. (2008). A scoping study on student well-being. Canberra: Department of Education, Employment \& Workplace Relations. Retrieved from https://docs.education.gov.au/system/files/doc/other/scoping_study_into_approaches_to_student_w ellbeing_final_report.pdf

Norrish, J. M., \& Vella-Brodrick, D. A. (2009). Positive psychology and adolescents: Where

are we now? Where to from here? Australian Psychologist, 44(4), 270-278. https://doi.org/10.1080/00050060902914103

Norrish, J. M., Williams, P., O'Connor, M., \& Robinson, J. (2013). An applied framework for positive education. International Journal of Wellbeing, 3(2), 147-161.

Park, N., \& Peterson, C. (2009). Strengths of character in schools. In R. Gilman, E. S. Huebner, \& M. J. Furlong (Eds.), Handbook of positive psychology in schools (pp. 65-76). New York, NY: Routledge.

Peterson, C. (2006). A primer in positive psychology. New York, NY: Oxford University Press.

Patall, E. A., Cooper, H., \& Wynn, S. R. (2010). The effectiveness and relative importance of choice in the classroom. Journal of Educational Psychology, 102(4), 896-915.

http://psycnet.apa.org/doi/10.1037/a0019545 
Pattoni, L. (2012). Strengths-based approaches for working with individuals. The institute for Research and Innovation in Social Sciences. Retrieved from: https://www.iriss.org.uk/resources/insights/strengthsbased-approaches-working-individuals

Proyer, R. T., Ruch, W., \& Buschor, C. (2013). Testing strengths-based interventions: A preliminary study on the effectiveness of a program targeting curiosity, gratitude, hope, humor, and zest for enhancing life satisfaction. Journal of Happiness Studies, 14(1), 275-292. http:/ / dx.doi.org/10.1007/ s10902-012-9331-9

Quinlan, D., Swain, N., \& Vella-Brodrick, D. A. (2012). Character strengths interventions: Building on what we know for improved outcomes. Journal of Happiness Studies, 13(6), 1145-1163. http://dx.doi.org/10.1007/s10902-011-9311-5

Quinlan, D. M., Swain, N., Cameron, C., \& Vella-Brodrick, D. A. (2015). How 'other people matter' in a classroom-based strengths intervention: exploring interpersonal strategies and classroom outcomes. The Journal of Positive Psychology, 10(1), 77-89. http:/ / dx.doi.org/10.1007/s10902-011-9311-5.

Rapp, C. A., Saleebey, D., \& Sullivan, W. P. (2006). The future of strengths-based social work. Advances in Social Work: Special Issue on the Futures of Social Work, 6(1), 79-90.

Rawana E., Latimer K., Whitley J., \& Probizanski M. (2009). Strength-based classroom strategies for teachers. Canadian Teacher magazine. BC Canada: Pacific Edge publishing. Retrieved from https://canadianteachermagazine.com/issues/2009/CTM-Nov09-web/

Ruch, W., Weber, M., Park, N., \& Peterson, C. (2014). Character strengths in children and adolescents: Reliability and initial validity of the German Values in action inventory of strengths for youth (German VIA-Youth). European Journal of Psychological Assessment, 30(1), 57-64. http://dx.doi.org/10.1007/s10902011-9311-5

Savin-Baden, M., \& Major, C. H. (2013). Qualitative research: The essential guide to theory and practice. Oxford, UK: Routledge.

Schunk, D. H., \& Mullen, C. A. (2012). Self-efficacy as an engaged learner. In S. L. Christenson, A. L. Reschly, \& C. Wylie (Eds.), Handbook of research on student engagement (pp. 219-235). New York, NY: Springer. https://doi.org/10.1007/978-1-4614-2018-7_10

Seligman, M. E. (2012). Flourish: A visionary new understanding of happiness and well-being. Sydney, Australia: Simon and Schuster.

Seligman, M. E., Ernst, R. M., Gillham, J., Reivich, K., \& Linkins, M. (2009). Positive education: Positive psychology and classroom interventions. Oxford Review of Education, 35(3), 293-311. http:/ / dx.doi.org/10.1080/03054980902934563

Sharp, J. (2012). Success with your education research project (2nd ed.). London, England: Sage.

Shoshani, A., \& Slone, M. (2013). Middle school transition from the strengths perspective: Young adolescents' character strengths, subjective well-being, and school adjustment. Journal of Happiness Studies, 14(4), 1163-1181. http:/ / psycnet.apa.org/doi/10.1007/s10902-012-9374-y

Stebleton, M. J., Soria, K. M., \& Albecker, A. (2012). Integrating strength-based education into a first-year experience curriculum. Journal of College and Character, 13(2), 1-8. https:/ / doi.org/10.1515/jcc-2012-1877

Stewart, D. W., \& Shamdasani, P. N. (2014). Focus groups: Theory and practice (3rd ed.). Thousand Oaks, CA: Sage.

Tuckman, B. W., \& Harper, B. E. (2012). Conducting educational research. Lanham, MD: Rowman \& Littlefield Publishers.

Veronneau, M. H., Koestner, R. F., \& Abela, J. R. Z. (2005). Intrinsic need satisfaction and well-being in children and adolescents: An application of the self-determination theory. Journal of Social and Clinical Psychology, 24(2), 280-292.

Waters, L. (2015). The relationship between strength-based parenting with children's stress levels and $\begin{array}{lllll}\text { strength-based } \quad \text { coping } & \text { approaches. }\end{array}$ http:/ / dx.doi.org/10.4236/psych.2015.66067

Waters, L (2017). The Strength Switch: how the new science of strength-based parenting can help you and your child flourish. New York, NY: Avery.

White, M., \& Waters, L. E. (2015). A case study of 'The Good School:' Examples of the use of Peterson's strengths-based approach with students. The Journal of Positive Psychology. https:/ / doi.org/10.1080/17439760.2014.920408

Yin, R. K. (2013). Case studies research: Design and methods (5th ed.). Thousand Oaks, CA: Sage. 